\title{
Weak Form Market Efficiency of the Johannesburg Stock Exchange: Pre, During and Post the 2008 Global Financial Crisis
}

\author{
Olwetu Fusthane, Kapingura FM \\ University of Fort Hare, East London Campus, East London, South Africa \\ FKapingura@ufh.ac.za
}

\begin{abstract}
The importance of the efficiency of the stock market cannot be underestimated, given the critical role the stock market plays through brings together those who demand and supply development finance. It is against this background that this study focused on analysing the weak form efficiency of the Johannesburg Stock Exchange for the period 2005 to 2016 utilising several methodologies which include unit root tests, autocorrelation test and variance ratio. The empirical results from unit root tests indicated that the null hypothesis of a random walk could not be rejected. The same also applied to the autocorrelation test and variance ratio test except for a few instances. Thus irrespective of the few instances which represent the inefficiency of the market, to a greater extent there is evidence of the market being weak form efficient. Thus even though the work done towards ensuring that the market is efficient is commendable, there is need to ensure that further steps are taken to enhance the efficiency of the market. This is, to some extent suggest that investors are able to make abnormal profits from the market.
\end{abstract}

Keywords: JSE, unit root tests, autocorrelation test, variance ratio

\section{Introduction}

Background to the Study: The efficiency of the stock market is considered to be a very important aspect in the financial markets considering the role that it plays in the mobilisation and allocation of development capital to the broader economy. Fama (1970) defines market efficiency as the speed with which security prices reflect all the available information. There are three different forms of market efficiency: the weak form, semi-strong form and the strong form. The weak form emphasises the role of the historical information in the determination of stock prices. In the semi-strong form, the emphasis is on the role played by the historical information as well as all the publicly available information. Lastly with regards to the strong form, security prices will be reflecting the historical, publicly available as well as privately available information. In this regard there is no possibility of someone 'beating' the market. Studies which have examined the importance of the stock market highlight the important role it plays in promoting economic growth (Fama, 1970; Yartey and Adjasi, 2007; Ovat, 2012; Owusu, 2016). These studies highlight that an efficient and liquid stock market is able to efficiently generate and allocate development capital to productive sectors of the economy. This therefore enhances the prospects of a long-term growth of the economy. There are a number of studies which have highlighted the importance of the stock market efficiency in general. These studies include Bonga-Bonga (2012); Appiah-Kusi and Myenyah (2003) and Simons \& Laryea (2005), though conclusions have been varied. There is another strand of literature which has highlighted the extent to which a well-established and integrated stock market may propagate a financial crisis. These studies include Jethwani and Acthuthan (2013), Todae and Lazar (2012), Abraham, Seyyed \& Alsakran (2002). These studies highlight that the stock market may transmit a crisis from one country to another.

It is interesting to note that South Africa is one of the countries in Africa that has a well-established financial system. According to Strate (2015) South Africa's stock market (Johannesburg Stock Exchange) was ranked number $12^{\text {th }}$ in terms of financial market development amongst 140 countries, ranked second for regulation of securities exchanges, ranked sixth for availability of financial services and lastly ranked eighth for soundness of banks. This has played a very important role in the growth of the country. A number of steps have been carried out to enhance the efficiency of the JSE. This includes the establishment of the Stock Exchange News Service (SENS) in August 1997 with the aim of facilitating the release of information which is regarded as price sensitive. However, despite all the developments which have taken place in the stock market, the efficiency of the stock market is still a cause of concern. The report in the Business tech of the $10^{\text {th }}$ of April 2017 highlight that the exchange was investigating suspicious trading activities after the removal of Mr Gordhan as the finance minister which may suggest that there are investors who may make abnormal profits from the exchange. Thus, this study examined the efficiency of the JSE, specifically focusing on whether 
the market is efficient in the weak form. Unlike the previous studies which have analysed this kind of relationship, the study contributes to a greater extent by analysing three different periods, namely before, during and after the Global financial crisis.

\section{Literature Review}

The bulky of the available literature on the efficiency of the stock market is concentrated mostly in developed countries due to the development of stock markets in those countries as compared to the emerging and developing countries. The majority of these studies largely utilised serial correlation and runs tests. However, recently the variance ratio test has also featured as a method of analysis in the literature. Of the studies carried out in developed countries, Worthington and Higgs (2004) carried out a study on 16 developed countries and four emerging economies utilising four methods of analysis. The results indicated that in developed European markets the random walk hypothesis cannot be rejected. This implies that investors cannot predict and profit from previous prices of the stock market. In a separate study, Lima and Tabak (2004) found that the random walk hypothesis could not be rejected for the Hong equity market, whilst for Singapore it was rejected.

On the other hand, studies carried out on emerging stock markets presents mixed results. There are studies which have established both the presence and absence of the random walk (Appiah-Kusi \& Menyah, 2003; Smith \& Ryoo, 2003). On the other hand, there are studies which have established the presence of the random walk (Gilmore \& McManus, 2003; Abrosimova et al., 2005; Tas \& Dursonoglu, 2005). Lastly there are those studies which have established the absence of the random walk (Akinkugbe, 2005; Okpara, 2010). Chung (2006) highlight that the mixed results on emerging economies are not surprising considering that emerging economies stock markets are not efficient as compared to developed countries stock markets. There are a number of challenges with emerging economies such as high levels of illiquidity and thin trading activity (Khaled and Islam, 2005). Emerging economies also lack market depth, there is high information asymmetry coupled with a weak infrastructure.

In South Africa there are also a number of studies which have been carried out examining the efficiency of the stock market (Affleck-Graves, 1975; Smith and Jefferies, 2002; Magnusson and Wydick, 2002; Appiah-Kusi \& Menyah, 2003; Mabhunu, 2004; Cubbin et al., 2006; Jefferies \& Smith, 2008; Smith, 2008; Bonga-Bonga and Mwamba, 2011; Bonga-Bonga, 2012; Van Heerden et al., 2013). The studies also established mixed results. The difference in results was largely attributed to the different methodologies used in the studies. Van Heerden et al. (2013) highlight that there are methodological issues with the previous studies in that they assumed a linear relationship which is not always the case. The majority of these studies established that the JSE is weak form efficient. This study improves on the previous studies through employing more than one technique under three different periods.

\section{Data and Methodology}

The data utilised in the study was obtained from the Bloomberg database. The data comprises of the FTSE/JSE All Share Index, FTSE/JSE Financials, FTSE/JSE Resources and FTSE/JSE Industrials data from 2005 to 2016 in monthly series. Three different sample periods were utilised in the study, namely before the Global financial crisis (2005-2007), during the crisis (2008-2011) and after the crisis (2012-2016).

Theoretical Framework: The study is based on the random walk hypothesis which is attributed to Fama (1965). The author suggests that the random walk can occur under two hypotheses. The first hypothesis suggests that changes in stock prices should be independent of each other. The second hypothesis suggests that price changes should be subjected to some probability distribution. Based on the random walk model, the model used in the study is estimated in equation 1 as follows:

$R_{t}=\ln \left(\frac{P_{t}}{\left(P_{t}-1\right)}\right) x 100$ 
Where $R_{t}$ is the market at month $t . P_{t}$ is the market index at month $t$ and $P_{t-1}$ is the stock market index at month $t_{-1}$. The model suggests that the price of the stock does reflect all the available information which includes the previous value of the stock so that investors cannot make any abnormal profits through technical analysis. However, in the event that such a condition does not hold, that will be an indication of inefficiency in the market.

Estimation Techniques: Several methods have been utilised to examine the random walk model in a bid to obtain robust results. These methods include the unit root tests, the autocorrelation functions, and the variance test ratio. These tests are discussed in this section.

Unit root Tests: Random walk requires time series to comprehend a unit root and the unit roots tend to be non-stationary or tend to have a stochastic trend indicating a random walk. The unit root test is normally tested using three methodologies, namely the Dickey-Fuller test, Phillips-Perron, and Kwiatkowski, Phillps, Schmidt and Shin (KPSS). The unit root test is constructed to determine whether the series contain a unit root or is non-stationary. The study utilised the Augmented Dickey Fuller test and the Phillips-Perron test. The Augmented Dickey-Fuller tests utilise the following models (Alsayed, 2012):

$$
\begin{aligned}
& \Delta P_{t}=\beta p_{t-1}+\gamma_{j} \sum_{j=1}^{k} \Delta P_{t-j}+\varepsilon_{t} \\
& \Delta P_{t}=\mu+\beta p_{t-1}+\gamma_{j} \sum_{j=1}^{k} \Delta P_{t-j}+\varepsilon_{t} \\
& \Delta P_{t}=\mu+\alpha_{1} t+\beta p_{t-1}+\gamma_{j} \sum_{j=1}^{k} \Delta P_{t-j}+\varepsilon_{t}
\end{aligned}
$$

Where $\Delta$ represents the first difference and $P_{t}$ represents the variable being tested for unit roots, $(\mu)$ represents the constant, $\beta$ denotes the regression coefficients. The model incorporates the lagged term of the dependent variable represented by $k, t$ is the trend, $j$ is the lag length determined by the Akaike Information Criterion, $\alpha_{1}$ is the estimated coefficient for the trend, and $\varepsilon_{t}$ represents the random error term which is normally distributed with a mean of 0 and variance $\sigma^{2}$ which assumed to be white noise. The hypothesis to be tested by the model can be stated as follows:

$H_{0}: \beta=0$ (Non-stationary or unit root)

$\mathrm{H}_{1}: \beta<0$ (Stationary or no unit root)

The equation (2) is the first model, which does not include a constant and trend terms. The second model includes a constant term $(\mu)$, and the third model includes both a constant $(\mu)$ and the trend term $\left(\alpha_{1} t\right)$.

The second methodology used to test the unit root test is the Phillips-Perron (PP) non-parametric model established by Phillips and Perron (1988) in order to control the problem of serial correlation in the error terms when testing the unit root test. The authors constructed a non-parametric test with the following specification:

$$
\Delta y_{t-1}=\alpha_{0}+\gamma y_{t-1}+e_{t}
$$

Autocorrelation Function: For robust results, autocorrelation tests were also employed in this study. The autocorrelation is used for checking randomness in a data set. This randomness is determined by computing autocorrelations for data values at varying time lags. If random, such autocorrelations should be near zero for any and all time-lag separations. Therefore, if the autocorrelation is non-random, it means the autocorrelation is non-zero significant (Brooks, 2002). A mean reversal in the data series indicates that autocorrelation is negative, and that the null hypothesis is accepted, whereas if autocorrelation is positive the 
null hypothesis will not be accepted (Campbell et al., 1997). The equations estimated in estimating the correlation functions are specified as follows:

$$
\begin{aligned}
& p(k)=\frac{\operatorname{Cov}(r t, r t-k)}{\sqrt{\operatorname{Var}(r t)} \sqrt{\operatorname{Var}(r t-k)}}=\frac{\operatorname{Cov}(r t, r t-k)}{\operatorname{Var}(r t)} \\
& P(k)=\frac{\frac{1}{N-k} \sum_{n=k+1}^{N}\left(Z_{t}-\bar{Z}\right)(Z t-k-\bar{Z})}{\frac{1}{N} \sum_{n=1}^{N}\left(Z_{t}-\bar{Z}\right)^{2}}
\end{aligned}
$$

Variance Ratio Test: The variance ratio tests were also employed in the study so as to distinguish dependency of stock return series. It is used to test the heteroscedasticity and autocorrelation of the return series. Heteroscedasticity occurs when the variance of the error terms differ across observations. It is important to note that the null hypothesis of the white test is called homoscedasticity and if the null hypothesis is rejected, one can conclude that there is heteroscedasticity which represents a random walk process in the time series. Therefore, if there is heteroscedasticity of the residual, it suggests that the variance ratio test is not the same between price changes which is a basic assumption of the random walk hypothesis (Brooks, 2002). The hypothesis to be tested is stated as follows:

$\mathbf{H}_{\mathbf{0}}$ : No heteroscedasticity (meaning the series is homoscedastic)

$\mathbf{H}_{1}$ : There is heteroscedasticity (no homoscedasticity of variance)

The null hypothesis will be accepted if the probability value ( $p$-value) is greater than 0.05 or $5 \%$ significant level and the conclusion is that there is heteroscedasticity in the errors of the series.

\section{Results}

This section reports on the empirical evidence of the study, taking into account the analytical framework and model estimation techniques presented in the previous section. The first part of the analysis focuses on describing the descriptive statistics of the data and then describes the unit root tests using the augmented Dickey-Fuller test and Phillips-Perron, autocorrelation and lastly the variance ratio test.

Descriptive Statistics: Table $1(\mathrm{a})$ and $1(\mathrm{~b})$ presents descriptive statistics for monthly returns of the Johannesburg Stock Market indices (FSTE/JSE All-Share, FTSE/JSE Resources and FTSE/JSE Financials) for the period 2005-2016. This includes mean, maximum, minimum values and standard deviation, whereas $\mathrm{N}$ represents the number of observations. The descriptive statistics indicates that on average the All share market is volatile as depicted by the standard deviation. On the other hand, Table 1(a) also shows that resources the resources market is less volatile as compared to the financials.

Table 1(a): Descriptive statistics (2005-2016: January-March)

\begin{tabular}{lllll}
\hline Series & Mean & Maximum & Minimum & Standard deviation \\
\hline Jalsh & 34334.23 & 54440.43 & 18096.54 & 10610.41 \\
Resources & 26138.34 & 40194.63 & 13397.41 & 5093.625 \\
Financials & 26347.00 & 46641.91 & 13068.88 & 8905.352 \\
\hline
\end{tabular}

Source: Author's computation based on Eview 9

Table 1(b): Descriptive statistics (2005-2016: January-March)

\begin{tabular}{lllll}
\hline Series & Skewness & Kurtosis & Jarque-Bera & Jarque-Bera probability \\
\hline Jalsh & 0.466147 & 1.936431 & 10.41849 & 0.855466 \\
Resources & -0.120924 & 3.290312 & 0.743603 & 0.689491 \\
Financials & 0.819099 & 2.453899 & 15.53083 & 0.250424 \\
\hline
\end{tabular}

Source: Author's computation

Table 1(b) shows that all the series employed in the study are normally distributed as indicated by the Jarque-Bera test of 1041849 (prob 0.855466), 0.743603 (prob 0.689491) and 1.553083 (prob 0.250424) 
respectively. The returns for All Share (0.466147) and Financials (0.819099) are positively skewed, indicating a probability of frequent small increases whereas for Resources returns are (-0.120924) negatively skewed, indicating a greater probability of a large decrease in returns than rises. The kurtosis in all indices returns are not large, ranging from 1.936431 for All Share (JALSH) to 3.290312 for Resources.

Unit Root Tests: The Augmented Dickey-Fuller and Phillips-Perron tests were utilised in order to test the null hypothesis of the unit root. The results are reported in table 2(a, b, c and d) for Augmented Dickey Fuller and table 3 (a, b, c and d) for Phillips Perron.

Table 2(a): Augmented Dickey-Fuller test results for the full period

\begin{tabular}{llll}
\hline Series & \multicolumn{2}{l}{ ADF (Level Series) } & \\
& None & Constant & Constant and Trend \\
\hline FTSE/JSE ALSH & 1.9719 & -0.5542 & -1.7907 \\
Resources & -0.4094 & -2.1067 & -2.3979 \\
Financials & 1.7348 & -0.0397 & -1.4124 \\
ADF (First Difference Series) & & & \\
& None & Constant & Constant and Trend \\
FTSE/JSE ALSH & $-12.153^{* * *}$ & $-12.620^{* * *}$ & $-12.579^{* * *}$ \\
Resources & $-11.3015^{* * *}$ & $-11.2561^{* * *}$ & $-11.3826^{* * *}$ \\
Financials & $-11.1700^{* * *}$ & $-11.4106^{* * *}$ & $-11.4698^{* * *}$ \\
\hline
\end{tabular}

Notes: ${ }^{* * *}, 1 \%$ level ${ }^{* *}, 5 \%$ level ${ }^{*}, 10 \%$ levels

Sources: Author's computation

Table 2(b): Augmented Dickey-Fuller test results sample period (2005-2007)

\begin{tabular}{llll}
\hline Series & \multicolumn{2}{l}{ ADF (Level Series) } \\
& None & Constant & Constant and Trend \\
\hline FTSE/JSE ALSH & 2.4153 & -1.4046 & -1.7687 \\
Resources & 1.7573 & -1.3381 & -3.1791 \\
Financials & 0.8628 & -1.7553 & -1.2939 \\
ADF (First Difference Series) & & & \\
& None & Constant & Constant and Trend \\
FTSE/JSE ALSH & $-3.780^{* * *}$ & $-4.4604^{* * *}$ & $-4.4395^{* * *}$ \\
Resources & $-4.931^{* * *}$ & $-3.5146^{* * *}$ & $-3.2087^{* * *}$ \\
Financials & $-4.593^{* * *}$ & $-4.5951^{* * *}$ & $-4.6724^{* * *}$ \\
\hline
\end{tabular}

Notes: ***, $1 \%$ level $* *, 5 \%$ level $*, 10 \%$ levels

Sources: Author's computation

Table 2(c): Augmented Dickey-Fuller test results sample period (2008-2011)

\begin{tabular}{llll}
\hline Series & \multicolumn{2}{l}{ ADF (Level Series) } & \\
& None & Constant & Constant and Trend \\
\hline FTSE/JSE ALSH & 0.2976 & -1.0365 & -1.6754 \\
Resources & -0.4867 & -1.7197 & -1.6859 \\
Financials & 0.2149 & -1.1421 & -2.4169 \\
ADF (First Difference Series) & & & \\
& None & Constant & Constant and Trend \\
FTSE/JSE ALSH & $-7.1211^{* * *}$ & $-7.0317^{* * *}$ & $-7.2076^{* * *}$ \\
Resources & $-6.8531^{* * *}$ & $-6.8069^{* * *}$ & $-6.8919^{* * *}$ \\
Financials & $-7.6076^{* * *}$ & $-7.5271^{* * *}$ & $-7.7199^{* * *}$ \\
\hline
\end{tabular}

Notes: ${ }^{* *}, 1 \%$ level ${ }^{* *}, 5 \%$ level $*, 10 \%$ levels

Sources: Author's computation 
Table 2 (d): Augmented Dickey-Fuller test results sample period (2012-2016)

\begin{tabular}{llll}
\hline Series & \multicolumn{2}{l}{ ADF (Level Series) } & \\
& None & Constant & Constant and Trend \\
\hline FTSE/JSE ALSH & 1.5876 & -1.3440 & -1.7952 \\
Resources & -1.3262 & -0.8596 & -1.4970 \\
Financials & 1.5802 & -1.3669 & -1.7848 \\
ADF (First Difference Series) & & & \\
& None & Constant & Constant and Trend \\
FTSE/JSE ALSH & $-8.5718^{* * *}$ & $-9.2116^{* * *}$ & $-9.2579^{* * *}$ \\
Resources & $-7.7129^{* * *}$ & $-7.8542^{* * *}$ & $-7.8155^{* * *}$ \\
Financials & $-6.9014^{* * *}$ & $-7.2941^{* * *}$ & $-7.3086^{* * *}$ \\
\hline
\end{tabular}

Notes: ${ }^{* * *}, 1 \%$ level ${ }^{* *}, 5 \%$ level $*, 10 \%$ levels

Sources: Author's computation

The results from unit root test indicate that for all the sub-periods as well as the full period the null hypothesis of a unit root could not be rejected at level series. However, at first difference the results indicate that all the series are stationary. Thus the null hypothesis of a unit root could not be rejected at first difference. These results highlight that there is evidence of a random walk based on the ADF test. However, the unit root tests were also undertaken utilising the Phillips-Perron (PP) test. Almudhaf and Alkulaib (2013) highlights that the PP test is an improved version of the ADF as it takes into account the problem of autocorrelation.

Phillips-Perron test results: The Phillips-Perron test was also conducted so as to obtain robust results. The results of the PP test are discussed in the next section.

Table 3(a): Phillips-Peron test results for the full period

\begin{tabular}{llll}
\hline Series & \multicolumn{2}{l}{ PP (Level Series) } & \\
& None & Constant & Constant and Trend \\
\hline FTSE/JSE ALSH & 2.1215 & -0.5042 & -1.8171 \\
Resources & -0.4538 & -2.4829 & -2.6496 \\
Financials & 1.8399 & -0.0366 & -1.3586 \\
PP (First Difference Series) & & & \\
& None & Constant & Constant and Trend \\
FTSE/JSE ALSH & $-12.107^{* * *}$ & $-12.540^{* * *}$ & $-12.502^{* * *}$ \\
Resources & $-11.352^{* * *}$ & $-11.312^{* * *}$ & $-11.413^{* * *}$ \\
Financials & $-11.169^{* * *}$ & $-11.423^{* * *}$ & $-11.490^{* * *}$ \\
\hline
\end{tabular}

Notes: $^{* * *}, 1 \%$ level ${ }^{* *}, 5 \%$ level $*, 10 \%$ levels

Sources: Author's computation

Table 3(b): Phillips-Peron test results sample period (2005-2007)

\begin{tabular}{llll}
\hline Series & \multicolumn{2}{l}{ PP (Level Series) } & \\
& None & Constant & Constant and Trend \\
\hline FTSE/JSE ALSH & 2.5478 & -1.4317 & -1.9619 \\
Resources & 2.0279 & -1.3508 & -3.2278 \\
Financials & 0.9108 & -1.7555 & -1.2939 \\
PP (First Difference Series) & & & \\
& None & Constant & Constant and Trend \\
FTSE/JSE ALSH & $-3.8045^{* * *}$ & $-4.4121^{* * *}$ & $-4.4394^{* * *}$ \\
Resources & $-4.9401^{* * *}$ & $-5.9827^{* * *}$ & $-5.6992^{* * *}$ \\
\hline
\end{tabular}




\begin{tabular}{llll}
\hline Financials & $-4.593^{* * *}$ & $-4.5858^{* * *}$ & $-4.6682^{* * *}$ \\
\hline
\end{tabular}

Notes: ${ }^{* * *}, 1 \%$ level ${ }^{* *}, 5 \%$ level $*, 10 \%$ levels

Sources: Author's computation

Table 3(c): Phillips-Peron test results sample period (2008-2011)

\begin{tabular}{llll}
\hline Series & \multicolumn{2}{l}{ PP (Level Series) } & \\
& None & Constant & Constant and Trend \\
\hline FTSE/JSE ALSH & 0.2442 & -1.3083 & -1.7899 \\
Resources & -0.5001 & -1.9606 & -1.9121 \\
Financials & 0.2929 & -1.1421 & -2.3259 \\
PP (First Difference Series) & & & \\
& None & Constant & Constant and Trend \\
FTSE/JSE ALSH & $-7.0875^{* * *}$ & $-7.0083^{* * *}$ & $-7.1682^{* * *}$ \\
Resources & $-6.8388^{* * *}$ & $-6.7941^{* * *}$ & $-6.8873^{* * *}$ \\
Financials & $-7.6076^{* * *}$ & $-7.5271^{* * *}$ & $-7.7056^{* * *}$ \\
\hline
\end{tabular}

Notes: ${ }^{* *}, 1 \%$ level ${ }^{* *}, 5 \%$ level ${ }^{*}, 10 \%$ levels

Sources: Author's computation

Table 3(d): Phillips-Peron test results sample period (2012-2016)

\begin{tabular}{llll}
\hline Series & \multicolumn{2}{l}{ PP (Level Series) } & \\
& None & Constant & Constant and Trend \\
\hline FTSE/JSE ALSH & 1.9790 & -1.3824 & -1.5653 \\
Resources & -1.3199 & -0.9052 & -1.5646 \\
Financials & 1.7975 & -1.3872 & -1.8043 \\
PP (First Difference Series) & & & \\
& None & Constant & Constant and Trend \\
FTSE/JSE ALSH & $-8.4966^{* * *}$ & $-9.1864^{* * *}$ & $-9.8400^{* * *}$ \\
Resources & $-7.6863^{* * *}$ & $-7.8120^{* * *}$ & $-7.7774^{* * *}$ \\
Financials & $-6.9014^{* * *}$ & $-7.3688^{* * *}$ & $-7.4582^{* * *}$ \\
\hline
\end{tabular}

Notes: ${ }^{* * *}, 1 \%$ level ${ }^{* *}, 5 \%$ level $*, 10 \%$ levels

Sources: Author's computation

The PP test results for all the periods are consistent with the ADF tests. These results indicate that at level series the null hypothesis of a unit root could not be rejected. However, at first difference the series is stationary. The results indicate that for both the ADF and the PP tests all that was required was to difference the indices to make them stationary. As in Chung (2006) the results shows that there is evidence of random walk in all the series utilised in the study. These results are consistent with Smith and Jefferis (2002) and Magnusson and Wydick (2002). However, Chung (2006) highlight that the existence of a random walk may not necessarily imply that returns are unpredictable. In other words, the unit root tests results are not able to detect predictability in returns. Thus further tests were carried out which takes this into account.

Autocorrelation function: The results from autocorrelation functions are reported from table 4 (a) to table 4(d). Positive autocorrelations indicate that returns can be predicted in the short-horizon. On the other hand, negative autocorrelation highlight that there is mean reversion. In other words, negative autocorrelation is in line with an efficient market. 
Table 4(a): Autocorrelation test results

\begin{tabular}{|c|c|c|c|}
\hline & All Share & Resource & Financials \\
\hline & $\mathrm{AC}$ & $\mathrm{AC}$ & $\mathrm{AC}$ \\
\hline$P_{1}$ & -0.077 & -0.029 & -0.056 \\
\hline$P_{2}$ & 0.120 & -0.009 & 0.219 \\
\hline$P_{3}$ & 0.090 & -0.022 & 0.015 \\
\hline$P_{4}$ & 0.086 & 0.185 & 0.063 \\
\hline$P_{5}$ & 0.009 & 0.043 & -0.079 \\
\hline$P_{6}$ & -0.055 & -0.045 & -0.039 \\
\hline$P_{7}$ & 0.045 & 0.013 & -0.048 \\
\hline$P_{8}$ & -0.097 & 0.052 & -0.099 \\
\hline$P_{9}$ & 0.022 & 0.129 & 0.019 \\
\hline$P_{10}$ & -0.111 & -0.096 & -0.069 \\
\hline$P_{11}$ & 0.070 & 0.047 & 0.162 \\
\hline$P_{12}$ & -0.120 & -0.029 & -0.045 \\
\hline Q-stat & Q-stat & Q-stat & Q-stat \\
\hline $\mathrm{Q}(1)$ & $0.7454 *(0.388)$ & $0.1043^{* *}(0.530)$ & $0.3942 *(0.747)$ \\
\hline$Q(2)$ & $2.5777 *(0.276)$ & $0.1145^{* * *}(0.039)$ & $6.5136 *(0.944)$ \\
\hline$Q(3)$ & $3.6284 *(0.304)$ & $0.1742^{* * *}(0.088)$ & $6.5427 *(0.982)$ \\
\hline$Q(4)$ & $4.5976 *(0.331)$ & $4.6360 *(0.133)$ & $7.0554 *(0.327)$ \\
\hline$Q(5)$ & $4.6075 *(0.466)$ & $4.8832 *(0.164)$ & $7.8665 *(0.430)$ \\
\hline$Q(6)$ & $5.0073 *(0.543)$ & $5.1488 *(0.233)$ & $8.0707 *(0.525)$ \\
\hline$Q(7)$ & $5.2803 *(0.626)$ & $5.1715^{*}(0.301)$ & $8.3739 *(0.639)$ \\
\hline$Q(8)$ & $6.5457 *(0.586)$ & $5.5423 *(0.287)$ & $9.6913 *(0.698)$ \\
\hline$Q(9)$ & $6.6128 *(0.677)$ & $7.8167 *(0.372)$ & $9.7428 *(0.553)$ \\
\hline$Q(10)$ & $8.3073 *(0.599)$ & $9.0786 *(0.406)$ & $10.400 *(0.525)$ \\
\hline$Q(11)$ & $8.9935 *(0.622)$ & $9.3818 *(0.232)$ & $14.019 *(0.587)$ \\
\hline$Q(12)$ & $11.004 *(0.529)$ & $9.4982 *(0.282)$ & $14.299 *(0.660)$ \\
\hline
\end{tabular}

Notes: ${ }^{* * *}, 1 \%$ level ${ }^{* *}, 5 \%$ level $*, 10 \%$ levels

Sources: Author's computation

Table 4 (b): Panel A autocorrelation test results for the full period and Ljung Box Q-statistics sample period (2005-2007)

\begin{tabular}{llll}
\hline & All Share & Resource & Financials \\
\hline & AC & AC & AC \\
$P_{1}$ & -0.044 & -0.025 & -0.246 \\
$P_{2}$ & -0.140 & -0.099 & 0.016 \\
$P_{3}$ & -0.109 & 0.124 & -0.236 \\
$P_{4}$ & -0.084 & -0.108 & 0.057 \\
$P_{5}$ & 0.192 & -0.198 & 0.073 \\
$P_{6}$ & 0.051 & 0.241 & -0.017 \\
$P_{7}$ & 0.089 & -0.030 & 0.034 \\
$P_{8}$ & -0.258 & -0.188 & -0.203 \\
$P_{9}$ & -0.031 & -0.025 & -0.032 \\
$P_{10}$ & -0.083 & -0.022 & -0.098 \\
$P_{11}$ & 0.031 & -0.104 & 0.188 \\
$P_{12}$ & 0.018 & 0.109 & -0.013 \\
$\mathbf{Q}-\mathbf{s t a t}$ & $\mathbf{Q - s t a t}$ & $\mathbf{Q - s t a t}$ & $\mathbf{Q - s t a t}$ \\
$\mathrm{Q}(1)$ & & & \\
$\mathrm{Q}(2)$ & $0.0515^{*}(0.821)$ & $0.0175^{*}(0.200)$ & $1.6452^{*}(0.895)$ \\
$\mathrm{Q}(3)$ & $0.6046^{*}(0.739)$ & $0.2977^{*}(0.438)$ & $1.6529^{*}(0.862)$ \\
$\mathrm{Q}(4)$ & $0.9550^{*}(0.812)$ & $0.7526^{*}(0.346)$ & $3.3146^{*}(0.861)$ \\
\hline
\end{tabular}




\begin{tabular}{llll}
\hline & All Share & Resource & Financials \\
\hline$Q(5)$ & $2.3824^{*}(0.794)$ & $2.4071^{*}(0.610)$ & $3.5897^{*}(0.790)$ \\
$Q(6)$ & $2.4712^{*}(0.872)$ & $4.4148^{*}(0.731)$ & $3.5999^{*}(0.621)$ \\
$Q(7)$ & $2.7626^{*}(0.906)$ & $4.4482^{*}(0.820)$ & $3.6421^{*}(0.727)$ \\
$Q(8)$ & $5.3627^{*}(0.718)$ & $5.8243^{*}(0.731)$ & $5.2457^{*}(0.667)$ \\
$Q(9)$ & $5.4038^{*}(0.798)$ & $5.8498^{*}(0.809)$ & $5.2881^{*}(0.755)$ \\
$Q(10)$ & $5.7086^{*}(0.839)$ & $5.8708^{*}(0.838)$ & $5.7190^{*}(0.826)$ \\
$Q(11)$ & $5.7536^{*}(0.889)$ & $6.3879^{*}(0.765)$ & $7.4112^{*}(0.846)$ \\
$Q(12)$ & $5.7705^{*}(0.927)$ & $7.0090^{*}(0.829)$ & $7.4202^{*}(0.857)$ \\
\hline
\end{tabular}

Notes: ***, $1 \%$ level ${ }^{* *}, 5 \%$ level $*, 10 \%$ levels

Sources: Author's computation

Table 4 (c): Panel B autocorrelation test results for the full period and Ljung Box Qstatistics sample period (2008-2011)

\begin{tabular}{|c|c|c|c|}
\hline & All Share & Resource & Financials \\
\hline & AC & AC & AC \\
\hline$P_{1}$ & -0.008 & 0.032 & -0.107 \\
\hline$P_{2}$ & 0.102 & 0.184 & -0.078 \\
\hline$P_{3}$ & 0.180 & 0.072 & 0.011 \\
\hline$P_{4}$ & 0.101 & 0.036 & 0.131 \\
\hline$P_{5}$ & -0.094 & -0.246 & 0.050 \\
\hline$P_{6}$ & -0.110 & -0.078 & -0.106 \\
\hline$P_{7}$ & -0.019 & -0.093 & 0.047 \\
\hline$P_{8}$ & -0.207 & -0.260 & 0.065 \\
\hline$P_{9}$ & -0.130 & -0.005 & 0.017 \\
\hline$P_{10}$ & -0.171 & -0.139 & -0.180 \\
\hline$P_{11}$ & 0.010 & 0.104 & 0.035 \\
\hline$P_{12}$ & -0.089 & -0.069 & -0.086 \\
\hline Q-stat & Q-stat & Q-stat & Q-stat \\
\hline$Q(1)$ & $0.0036^{*}(0.952)$ & $0.0525^{*}(0.819)$ & $0.5764 *(0.448)$ \\
\hline$Q(2)$ & $0.5407^{*}(0.763)$ & $1.7815^{*}(0.410)$ & $0.8903 *(0.641)$ \\
\hline$Q(3)$ & $2.2316^{*}(0.526)$ & $2.0555^{*}(0.561)$ & $0.8966 *(0.826)$ \\
\hline$Q(4)$ & $2.7785^{*}(0.596)$ & $2.1242^{*}(0.713)$ & $1.8163^{*}(0.770)$ \\
\hline$Q(5)$ & $3.2652 *(0.659)$ & $5.4392 *(0.365)$ & $1.9561 *(0.855)$ \\
\hline$Q(6)$ & $3.9457^{*}(0.684)$ & $5.7772 *(0.449)$ & $2.5902 *(0.858)$ \\
\hline$Q(7)$ & $3.9661 *(0.784)$ & $6.2797 *(0.507)$ & $2.7152 *(0.910)$ \\
\hline$Q(8)$ & $6.4932 *(0.592)$ & $10.283^{*}(0.246)$ & $2.9640 *(0.937)$ \\
\hline$Q(9)$ & $7.5172 *(0.583)$ & $10.285^{*}(0.328)$ & $2.9811 *(0.965)$ \\
\hline$Q(10)$ & $9.3396 *(0.500)$ & $11.486^{*}(0.321)$ & $4.9930 *(0.892)$ \\
\hline$Q(11)$ & $9.3455^{*}(0.590)$ & $12.185^{*}(0.350)$ & $5.0697 *(0.928)$ \\
\hline $\mathrm{Q}(12)$ & $9.8636 *(0.628)$ & $12.495^{*}(0.407)$ & $5.5592 *(0.937)$ \\
\hline
\end{tabular}

Notes: ${ }^{* * *}, 1 \%$ level $* *, 5 \%$ level $*, 10 \%$ levels

Sources: Author's computation 
Table 4 (d): Panel C autocorrelation test results for the full period and Ljung Box Q-statistics sample period (2012-2016)

\begin{tabular}{|c|c|c|c|}
\hline & All Share & Resource & Financials \\
\hline & AC & AC & AC \\
\hline$P_{1}$ & -0.264 & -0.149 & -0.049 \\
\hline$P_{2}$ & 0.060 & 0.174 & -0.133 \\
\hline$P_{3}$ & -0.002 & 0.015 & 0.012 \\
\hline$P_{4}$ & -0.161 & -0.116 & -0.050 \\
\hline$P_{5}$ & 0.034 & -0.114 & 0.082 \\
\hline$P_{6}$ & 0.035 & 0.012 & 0.003 \\
\hline$P_{7}$ & -0.131 & -0.149 & -0.050 \\
\hline$P_{8}$ & 0.107 & 0.061 & 0.186 \\
\hline$P_{9}$ & 0.180 & 0.008 & -0.008 \\
\hline$P_{10}$ & -0.084 & -0.027 & -0.249 \\
\hline$P_{11}$ & 0.124 & 0.177 & 0.020 \\
\hline$P_{12}$ & -0.105 & 0.020 & -0.004 \\
\hline Q-stat & Q-stat & Q-stat & Q-stat \\
\hline$Q(1)$ & $4.6098^{* * *}(0.032)$ & $1.4762^{* *}(0.224)$ & $0.1575^{*}(0.691)$ \\
\hline$Q(2)$ & $4.8551^{* * *}(0.088)$ & $3.5086^{* *}(0.173)$ & $1.3417 *(0.511)$ \\
\hline$Q(3)$ & $4.8553 *(0.183)$ & $3.5239 * *(0.318)$ & $1.3520 *(0.717)$ \\
\hline$Q(4)$ & $6.6527^{*}(0.155)$ & $4.4612^{* *}(0.347)$ & $1.5250 *(0.822)$ \\
\hline$Q(5)$ & $6.7350 *(0.241)$ & $5.3771 * *(0.372)$ & $2.0053 *(0.848)$ \\
\hline$Q(6)$ & $6.8222 *(0.338)$ & $5.3874 * *(0.495)$ & $2.0061 *(0.919)$ \\
\hline$Q(7)$ & $8.0716 *(0.326)$ & $7.0032^{* *}(0.429)$ & $2.1919 *(0.948)$ \\
\hline$Q(8)$ & $8.9210^{* *}(0.349)$ & $7.2827^{* *}(0.506)$ & $4.7690 *(0.782)$ \\
\hline$Q(9)$ & $11.366^{* *}(0.251)$ & $7.2875 *(0.607)$ & $4.7739 *(0.854)$ \\
\hline$Q(10)$ & $11.909 * *(0.291)$ & $7.3433 *(0.693)$ & $9.5720 *(0.479)$ \\
\hline$Q(11)$ & $13.119 * *(0.286)$ & $9.8177^{* *}(0.547)$ & $9.6033^{*}(0.566)$ \\
\hline $\mathrm{Q}(12)$ & $14.005^{* *}(0.300)$ & $9.8493 *(0.629)$ & $9.6048 *(0.651)$ \\
\hline
\end{tabular}

Notes: ${ }^{* * *}, 1 \%$ level $* *, 5 \%$ level $*, 10 \%$ levels

Sources: Author's computation

The results in table 4 (a) highlight that for the entire period on average the autocorrelation functions are negative which suggest that the market if efficient. However, there are periods in which the autocorrelation functions are positive. The autocorrelation coefficient results indicate that even though the market to a greater extent is regarded as efficient, there are periods in which the returns are predictable. These results corroborate the findings of Hubbard and O'Brien (2012), Hassan et al. (2006). These authors highlight that emerging markets exhibit strong serial correlation highlighting the imperfections inherent in these markets.

Variance Ratio Test: The results of the variance ratio test are reported on table 5(a) to table 5(d). The variance test was conducted for various lags $(2,4,8$ and 16) for each index. The variance of the returns are represented by $\operatorname{VR}(\mathrm{q})$. On the other hand $\mathrm{Z}(\mathrm{q})$ and $\mathrm{Z}^{*}(\mathrm{q})$ represents the statistics of the variance ratio under the assumption of homoscedasticity and heteroscedasticity respectively.

Table 5(a): Panel A: Full period 2005-2016 variance ratio test

\begin{tabular}{lllllll}
\hline Time series & $\mathbf{N}$ & & $\mathbf{2}$ & $\mathbf{4}$ & $\mathbf{8}$ & $\mathbf{1 6}$ \\
\hline JALSH & 124 & VR(q) & 0.9251 & 1.0827 & 1.3479 & 1.3361 \\
& 124 & Z(q) & -1.3720 & -0.2934 & 0.2565 & 0.4081 \\
Resources & 124 & $Z^{*}(\mathrm{q})$ & -0.5910 & 0.3692 & 1.019 & 0.6803 \\
& 124 & VR(q) & 0.1028 & 0.2008 & 0.3067 & 0.4353 \\
& 124 & Z(q) & -0.0854 & 1.3206 & 1.1592 & 0.5225 \\
& 124 & $Z^{*}(q)$ & -0.4916 & 0.8345 & 0.9548 & 0.4995 \\
\hline
\end{tabular}




\begin{tabular}{lllllll}
\hline Time series & $\mathbf{N}$ & & $\mathbf{2}$ & $\mathbf{4}$ & $\mathbf{8}$ & $\mathbf{1 6}$ \\
\hline Financials & 124 & VR(q) & 0.9775 & 0.9608 & 1.2134 & 1.5317 \\
& 124 & Z(q) & -0.3247 & -0.4786 & 0.3857 & 1.0016 \\
& 124 & $\mathrm{Z}^{*}(\mathrm{q})$ & -0.2005 & -0.1926 & 0.6411 & 1.0820 \\
\hline
\end{tabular}

Notes: ${ }^{* * *}, 1 \%$ level ${ }^{* *}, 5 \%$ level $*, 10 \%$ levels

Sources: Author's computation

Table 5(b): Panel B: 2005-2007 variance ratio test results

\begin{tabular}{lllllll}
\hline Time series & $\mathbf{N}$ & & $\mathbf{2}$ & $\mathbf{4}$ & $\mathbf{8}$ & $\mathbf{1 6}$ \\
\hline JALSH & 124 & VR(q) & 0.8744 & 0.4987 & 0.6879 & 1.0591 \\
& 124 & Z(q) & -0.6151 & -1.3126 & -0.5167 & $0.0658^{* * *}$ \\
Resources & 124 & $Z^{*}(\mathrm{q})$ & -0.5249 & -1.2250 & -0.5537 & $0.0818^{* * *}$ \\
& 124 & VR(q) & 0.7008 & 0.3363 & 0.3669 & 0.3595 \\
& 124 & Z(q) & -1.4654 & -1.7378 & -1.0484 & -0.7127 \\
Financials & 124 & $Z^{*}(\mathrm{q})$ & -1.7318 & -2.0715 & -1.2437 & -0.9095 \\
& 124 & VR(q) & 0.9828 & 0.9390 & 1.1322 & 1.0001 \\
& 124 & Z(q) & -1.4654 & -1.7378 & -1.0484 & -0.7127 \\
& 124 & $Z^{*}(\mathrm{q})$ & -0.0659 & -0.1389 & 0.2186 & $0.0002^{* * *}$ \\
\hline
\end{tabular}

Notes: ${ }^{* * *}, 1 \%$ level ${ }^{* *}, 5 \%$ level $*, 10 \%$ levels

Sources: Author's computation

Table 5(c): Panel C: 2008-2011 variance ratio test results

\begin{tabular}{lllllll}
\hline Time series & $\mathbf{N}$ & & $\mathbf{2}$ & $\mathbf{4}$ & $\mathbf{8}$ & $\mathbf{1 6}$ \\
\hline JALSH & 124 & VR(q) & 0.9784 & 1.2663 & 1.7562 & 1.0876 \\
& 124 & Z(q) & -0.1479 & 0.9760 & 1.7527 & 0.1365 \\
Resources & 124 & $\mathrm{Z}^{*}(\mathrm{q})$ & -0.1445 & 0.9604 & 1.7582 & 1.7582 \\
& 124 & VR(q) & 1.0117 & 1.3505 & 1.5125 & 0.8872 \\
\multirow{5}{*}{ Financials } & 124 & Z(q) & $0.0803^{* * *}$ & 1.2847 & 1.1880 & -0.1755 \\
& 124 & $\mathrm{Z}^{*}(\mathrm{q})$ & $0.0864^{* * *}$ & 1.0983 & 1.0195 & -0.1601 \\
& 124 & VR(q) & 0.9121 & 0.8506 & 1.0618 & 0.9113 \\
& 124 & Z(q) & -0.6023 & -0.5471 & 0.1433 & -0.1380 \\
& 124 & $\mathrm{Z}^{*}(\mathrm{q})$ & -0.5743 & -0.5345 & 0.1340 & -0.1341 \\
\hline
\end{tabular}

Notes: $^{* * *}, 1 \%$ level ${ }^{* *}, 5 \%$ level ${ }^{*}, 10 \%$ levels

Sources: Author's computation

Table 5(d): Panel D: 2012-2016 variance ratio test results

\begin{tabular}{lllllll}
\hline Time series & $\mathbf{N}$ & & $\mathbf{2}$ & $\mathbf{4}$ & $\mathbf{8}$ & $\mathbf{1 6}$ \\
\hline JALSH & 124 & VR(q) & 0.7573 & 0.7114 & 0.5519 & 0.6869 \\
& 124 & Z(q) & -1.9257 & -1.2242 & -1.2021 & -0.5645 \\
\multirow{5}{*}{ Resources } & 124 & $\mathrm{Z}^{*}(\mathrm{q})$ & -1.6598 & -1.0842 & -1.1061 & -0.5509 \\
& 124 & VR(q) & 0.8653 & 1.0098 & 0.936768 & 1.1484 \\
& 124 & Z(q) & -1.0686 & $0.0417^{* * *}$ & -0.1696 & 0.2677 \\
Financials & 124 & $\mathrm{Z}^{*}(\mathrm{q})$ & -0.9740 & 0.0388 & -0.1655 & 0.2756 \\
& 124 & VR(q) & 0.9716 & 0.8555 & 0.8094 & 0.6142 \\
& 124 & Z(q) & -0.2248 & -0.6129 & -0.5113 & -0.6955 \\
& 124 & $\mathrm{Z}^{*}(\mathrm{q})$ & -0.1803 & -0.4915 & -0.4084 & -0.5879 \\
\hline
\end{tabular}

Notes: ${ }^{* * *}, 1 \%$ level ${ }^{* *}, 5 \%$ level ${ }^{*}, 10 \%$ levels

Sources: Author's computation

The results from the variance ratio as reported on table 4.4.1 (a) indicate that the null hypothesis of a random walk cannot be rejected at all lags since all the associated probability tests are greater than $10 \%$ level of significance. On table 4.4.1 (b) the null hypothesis could not be rejected also except for JALS at lag 16 and for financials under $\mathrm{Z}^{*}(\mathrm{q})$. These results suggest that even though to a greater extent the JSE is efficient in the weak form, there are periods in which investors are able to predict returns. The same applies in table 4.4.1 (c) 
under resources at lag 2 and lastly on table 4.4.1(d) at lag 4. The overall findings, based on the variance ratio test, even though there are few periods in which the test statistics were significant, indicate that the indices have become more efficient over time. These results are consistent with Hubbard and O’Brien (2012).

\section{Conclusion}

The study examined the weak form market efficiency of the JSE, specifically looking at the extent to which the market follows the random walk model. The study was motivated by the important role which the stock market plays in mobilising and allocating development finance which is a very important driver of economic growth. Unlike the previous studies in the area, three estimation techniques were utilised in examining the efficiency of the JSE. Firstly, the unit root test results indicate that the null hypothesis of a random walk could not be rejected at first difference series. However, for the autocorrelation tests and variance ratio tests the results are mixed. This suggests that even though the market is efficient in the weak form, to a greater extent, there are some periods where the market is not efficient and investors are able to exploit and come up with arbitrage portfolios based on trading rules. The key issue which emerges from the study is that the efficiency of the stock market is of paramount importance to the broader economy. However, even though the effort which the JSE authorities have done towards ensuring efficiency of the market is commended, much still needs to be done. It is therefore recommended that there should be further implementation of polices targeted at curbing insider trading and market regulation so as to enhance the efficiency of the stock market. There is need to also improve market conduct and financial market infrastructure. These approaches are likely to enhance the efficiency of the stock market.

\section{Reference}

Abraham, A., Seyyed, F. \& Alsakran, S. (2002). Testing the RW behaviour and efficiency of the Gulf Stock Markets. The Financial Review, 37, 469-480.

Abrosimova, N., Dissanaike, G. \& Linowski, D. (2005). Testing the Weak- Form Efficiency of the Russian Stock Market. Social Science Research Network (SSRN) Working Paper. [E-document] [Retrieved January 7, 2017] From: http://papers.ssrn.com/sol3/papers.cfm?abstract_id=302287.

Affleck-Graves, J. F. \& Money, A. H. (1975). A Note on the Random Walk Model and South African Share Prices. South African Journal of Economics, 43(3), 382-388

Akinkugbe, O. (2005). Efficiency in Botswana Stock Exchange: An Empirical Analysis. The Business Review, $4(2), 223-230$.

Almudhaf, F. \& Alkulaib, Y. (2013). Are CIVETS Stock Markets Predictable? Academy Of Accounting \& Financial Studies Journal, 17(3), 1-12.

Alsayed, M. S. (2012). Weak-form efficiency: Evidence form Dow Jones Islamic Indices. Available from: http://glofin.org/index.php?option=com_civicrm\&task=civicrm/file\&reset=1\&id=473\&eid=1068 [20 March 2016].

Appiah-Kusi, J. \& Menyah, K. (2003). Return predictability in African Stock Markets. Review of Financial Economics, 12(3), 247-270.

Bonga-Bonga, L. (2012). The evolving efficiency of the South African Stock Exchange. International Business \& Economics Research Journal, 11(9), 997-1002.

Bonga-Bonga, L. \& Mwamba, M. (2011). The predictability of stock market returns in South Africa: Parametric Vs. Non-Parametric methods. South African Journal of Economics, 79(3), 301-311.

Brooks, C. (2002). Introductory econometrics for finance. 2nd ed. Cambridge: Cambridge University Press.

Businesstech (2017). JSE to investigate 'dodgy trades' around Gordhan axing: report, Available at< https://businesstech.co.za/news/finance/169589/jse-to-investigate-dodgy-trades-around gordhanaxing-report/ >, Accessed on 12 April 2017.

Campbell, J. Y., Lo, A. W. \& MacKinlay, A. C. (1997). The econometrics of financial markets. 2nd ed. Princeton: Princeton University Press.

Chung, H. Y. (2006). Testing Weak-Form Efficiency of the Chinese Stock Market, the Department of Business Administration in Lappeenranta University of Technology, Unpublished dissertation.

Cubbin, E., Eidne, M., Firer, C. \& Gilbert, E. (2006). Mean reversion on the JSE. Investment Analysts Journal, 63(1), 1-17.

Cuthbertson, K. (1996). Quantitative financial economics. England: John Wiley \& Sons Ltd. 
Dickey, D. A. \& Fuller, W. A. (1979). Distribution of the estimators for autoregressive time series with a unit root. Journal of the American Statistical Association, 74, 427-431.

Fama, E. F. (1965). The behaviour of stock market prices. Journal of Business, 38, 34-105.

Fama, E. F. (1970). Efficient capital markets: a review of theory and empirical work. Journal of Finance, 25, 383-417.

Foley, B. J. (1991). Capital markets. Hong-Kong: Macmillan.

Gilmore, C. G. \& McManus, G. M. (2003). Random Walk and Efficiency Tests of Central European Equity Markets. Managerial Finance, 29(4), 42-61.

Hamman, W. D., Jordaan, F. \& Smit, F. (1995). Random Walk Hypothesis: Evidence from the JSE. South African Journal of Economics, 57(1), 69-78.

Hassan, K. M., Haque, M. \& Lawrence, S. (2006). An Empirical Analysis of Emerging Stock Markets of Europe. Quarterly Journal of Business and Economics, 45(1\&2), 31-52.

Hubbard, P. \& O'Brien, P. (2012). Money, banking and the financial system. Hoboken, NJ: Pearson Education.

Jefferis, K. \& Smith, G. (2005). The Changing Efficiency of African Stock Markets. South African Journal of Economics, 73, 54-67

Jethwani, K. \& Achuthan, S. (2013). Stock Market efficiency and crisis: Evidence from India. Asia-Pacific Finance and Accounting Review, 1(2), 35-43.

Kendall, M. G. (1950). The analysis of economic time series 1. Journal of Royal Statistical Society, 1(116), 1125.

Khaled, M. \& Islam, A. (2005). Test of Weak-Form Efficiency of the Dhaka Stock Exchange. Journal of Business Finance \& Accounting, 32(7\&8), 1613-1624.

Lima, E. J. \& Tabak, B. M. (2004). Tests of the random walk hypothesis for equity markets: evidence from China, Hong Kong and Singapore. Applied Economic Letters, 11, 255-258.

Lo, A. W. \& MacKinlay, A. C. (1988). Stock market prices do not follow random walks: Evidence from a simple specification test. Review of Financial Studies, 1(1), 41-66.

Magnusson, M. \& Wydick, B. (2002). How efficient are Africa's emerging stock markets? Journal of Development Studies, 38(4), 141-156.

Mabhunu, M. (2004). The Market Efficiency Hypothesis and the behaviour of stock returns on the JSE Securities Exchange. Unpublished Masters thesis, Rhodes University.

Mobarek, A. \& Keasey, K. (2002). Weak-Form Market Efficiency of and Emerging Market: Evidence from Dhaka Stock Market of Bangladesh. [E-document] [Retrieved October 26, 2016] From: http://www.bath.ac.uk/centers/CDS/Enbs-papers/Mobarek_new.htm.

Okpara, G. (2010). Stock market prices and the Random walk hypothesis: Further Evidence from Nigeria. Journal of Economics and International Finance, 2(3), 49-57.

Ovat, O. O. (2012). Stock Market Development and Economic Growth in Nigeria: Market Size versus Liquidity. Can. Soc. Sci, 8.

Owusu, E. L. (2016). Stock Market and Sustainable Economic Growth in Nigeria, Economies 2016, 4, 25.

Phillips, P. C. B. \& Perron, P. (1988). Testing for a unit root in time series regression. Biometrika, 75, 335-346.

Simons, D. \& Laryea, S. A. (2005). Testing the efficiency of African Markets. Available from: http://ssrn.com/abstract=Accessed [15 November 2015].

Smith, G. \& Jefferis, K. (2002). African stock markets: multiple variance ratio tests of random walks. Applied Financial Economics, 12(4), 475-484.

Smith, G. (2008). Liquidity and the informational efficiency of African Stock Markets. South African Journal of Economics, 76(2), 161-175.

Smith, G. \& Ryoo, H. J. (2003). Variance ratio tests of the random walk hypothesis for European emerging stock markets. The European Journal of Finance, 9, 290-300.

Strate. (2015). 2015-2016, Global Competitive Index report published by World Economic Forum. South Africa's Financial Market Development Continues to rank in Top 20.http:www.strate.co.za; Accessed [17 January 2017].

Tas, O. \& Dursonoglu, S. (2005). Testing random walk hypothesis for Istanbul Stock Exchange. International Trade and Finance Association Conference Papers. [E-document] [Retrieved March 23, 2017] From: http://services.bepress.com/otfa/15th/art38.

Todae, A. \& Lazar, D. (2012). Global crisis and relative efficiency: Empirical evidence from Central and Eastern European stock markets. The Review of Finance and Banking, 4(1), 45-53. 
Van Heerden, D., Rodrigues, J., Hockly, D., Lambert, B., Taljard, T. \& Phiri, A. (2013). Efficient Market Hypothesis in South Africa: Evidence from a threshold autoregressive (TAR) model, Munich Personal RePEc Archive [Online], Available on <http//mpra.ub.uni-muenchen.de/50544/, Accessed on 17 November 2016.

Worthington, A. C. \& Higgs, H. (2004). Random walks and market efficiency in European equity markets. Global Journal of Finance and Economics, 1(1), 59-78.

Yartey, C. O. \& Adjasi, C. K. (2007). Stock Market Development in Sub Saharan Africa: Critical Issues and Challenges. International Monetary Fund working paper, P. wp/07/209. 